\title{
HUBUNGAN ANTARA ADVERSITI DAN INTELIGENSI DENGAN KREATIVITAS
}

\author{
Siti Ma'rifah Setiawati, S.Psi \\ Guru Bimbingan Dan Konseling MTs Negeri III Surabaya \\ email: marifah0404@gmail.com
}

\begin{abstract}
Abstrak
Penelitian ini bertujuan untuk mengetahui hubungan antara adversiti dan inteligensi dengan kreativitas. Penelitian ini dilakukan pada siswa-siswa MTs Negeri III Surabaya. Jumlah sampel yang digunakan adalah 92 siswa kelas 8. Berdasarkan hasil analisis regresi diperoleh nilai $F=6,401$ dengan sig. $=0,042$ yang berarti ada hubungan antara adversiti dan inteligensi dengan kreativitas. Untuk melihat subangan efektif masil-masil variabel diperoleh 19,12\% sumbangan variabel adversiti terhadap kreativitas siswa, dan 30,23\% sumbangan variabel inteligensi terhadap kreativitas siswa. Semakin seorang siswa mempunyai respon yang baik atau mempunyai kemampuan untuk bertahan dan kemampuan mengatasi kesulitan yang dihadapi serta didukung oleh kecerdasan yang cukup tinggi, maka semakin tinggi pula kreativitas atau semangat berkreasinya.
\end{abstract}

\section{Kata Kunci : Adversiti, Inteligensi, Kreativitas}

\section{PENDAHULUAN}

Seperti yang tertuang didalam GBHN 1993, dengan penekanan bahwa pendidikan nasional bertujuan untuk meningkatkan kualitas manusia Indonesia yaitu manusia yang beriman dan bertaqwa terhadap Tuhan Yang Maha Esa, berbudi pekerti luhur, berkepribadian, mandiri, maju, tangguh, cerdas, kreatif, terampil, berdisiplin, beretos kerja, profesional, bertanggung jawab, dan produktif, serta sehat jasmani dan rohani, maka kreativitas merupakan salah satu aspek atau elemen dari kualitas manusia. Hal ini sesuai dengan pernyataan Maslow (dalam Munandar, 1999), bahwa dengan berkreasi orang dapat mewujudkan dirinya, dan perwujudan diri merupakan kebutuhan pokok pada tingkat tertinggi dalam hidup manusia, maka kreativitas merupakan manifestasi 
dari individu yang berfungsi sepenuhnya atau yang berkualitas. Oleh karena itu sumbangan kreatif siswa-siswa Indonesia memegang peran penting, sebab dengan kreativitas memungkinkan manusia meningkatkan kualitas hidupnya sehingga kebutuhan untuk mencetak tunas muda yang mampu mengatasi krisis yang sedang melanda bangsa dan negara Indonesia akan terpenuhi.

Namun gejala yang nampak pada siswa-siswi Indonesia, kreativitasnya masih tergolong rendah. Para siswa jarang mengemukakan ide-ide kreatif pada saat mengikuti pelajaran dikelas, kebanyakan pasif dan hanya melakukan apa yang dtugaskan guru tanpa usaha atau tanpa adanya semangat untuk berkreasi didalam membangun diskusi. Menurut Hermans (dalam Monks, 1989), siswa yang pasif dan tidak mempunyai semangat memunculkan ide-ide kreatifnya, terutama disebabkan olehketakutan akan gagal. Ketakutan akan gagal siswa jaman sekarang mungkin berhubungan dengan situasi pengajaran, juga dengan situasi hidup keseluruhan, dan sebagian disebabkan karena siswa makin dihadapkan dengan kemungkinan pilihan yang lebih banyak di dalam maupun di luar situasi pengajaran, sehingga kapasitas intelektual tidak sepenuhnya dapat bekerja. Situasi pengajaran atau pendidikan di Indonesia penekanannya lebih pada pemikiran reproduktif, hafalan, dan mencari satu jawaban yang benar terhadap soal-soal yang diberikan, pemberian kemungkinan jawaban yang lain akan dianggap sebagai suatu kegagalan, maka siswa kurang terlatih untuk merespon kesulitan yang dihadapi dengan baik. Siswa hanya melakukan proses berpikir konvergen dan siswa kurang tertantang untuk melaksanakan proses berpikir divergen atau berpikir kreatif yang memungkinkan siswa mampu melihat bermacammacam kemungkinan jawaban atau penyelesaian terhadap suatu masalah. Hal ini sesuai dengan ungkapan guru besar Psikologi Universitas Indonesia dan juga pakar kreativitas yakniMunandar (1999), yang menemukan di dalam penelitiannya bahwa kreativitas bangsa Indonesia 
masih tergolong rendah dan ada kecenderungan kreativitas di Indonesia tidak dapat berkembang secara optimal di kalangan subyek didik, demikian juga pendapat Guilford (1950), yang menyatakan bahwa pengembangan kreativitas ditelan- tarkan dalam pendidikan formal padahal ini amat bermakna bagi pengembangan potensi individu secara utuh dan bagi kemajuan ilmu pengetahuan serta seni budaya. Oleh karena kurang terlatih melakukan proses berpikir yang menantang, siswa tidak mampu melihat kemungkinan bermacam-macam solusi penyelesaian masalahnya sehingga siswa Indonesia melakukan respon yang buruk terhadap kesulitan yang dihadapi atau kurang mampu bertahan terhadap kesulitan yang terjadi didalam mengatasi masalahnya.

Kemampuan bertahan dan mengatasi kesulitan didalam menghadapi tantangan atau kemampuan merespon kesulitan yang dihadapi dengan baik, oleh Stoltz (2000) diperkenalkan sebagai adversiti, sedangkan hasil pengukuran kemampuan bertahan dan mengatasi kesulitan terhadap permasalahan yang dihadapi disebut Adversity Quetient (AQ). Adversity Quotient menunjukkan seberapa jauh anak mampu bertahan meng- hadapi kesulitan dan seberapa jauh kemampuan anak untuk mengatasinya. Adversity Quotient juga meramalkan siapa yang mampu mengatasi kesulitan dan siapa yang hancur; siapa yang akan melampaui harapan-harapan atas kinerja dan potensinya serta siapa yang gagal ; siapa yang akan menyerah dan siapa yang akan bertahan. Menurut Stoltz (2000), orang yang adversity quotient-nya rendah, akan tumbuh menjadi orang yang tidak mampu bertindak kreatif.

Potensi dasar anak yang sering disebut sebagai inteligensi sangat menentukan didalam anak merespon kesulitan yang dihadapi, karena masyarakat umum sering mengatakan bahwa inteligensi terkait dengan kemampuan otak, kepintaran didalam memecahkan masalah yang diha- dapi. Hal ini sesuai dengan pendapat Gardner (dalam Munandar, 1999), yang menyatakan bahwa inteligensi merupakan kemampuan 
untuk memecahkan masalah atau untuk mencipta karya yang dihargai dalam satu kebudayaan atau lebih. Pendapat yang senada dikemukakan oleh H.H. Goddard (dalam Azwar, 1996), yang menyatakan bahwa inteligensi sebagai tingkat kemampuan pengalaman seseorang untuk menye- lesaikan masalahmasalah yang langsung dihadapi dan untuk mengantisipasi masalah yang akan datang. Oleh karena itu gambaran orang yang berinteligensi tinggi adalah orang yang cerdas, orang yang mudah menerima pelajaran, orang yang mampu memecahkan masalah dengan baik dan cepat, sehingga orang yang berinteligensi tinggi mampu membuat inovasi-inovasi baru dalam kehidupannya yang berarti mampu mengembangkan kreativitasnya sebab kreativitas merupakan proses penyatuan pengetahuan dari berbagai bidang pengalaman yang berlainan untuk menghasilkan ide-ide yang baru dan lebih baik. (West,M,2000).

\section{KREATIVITAS}

Kreativitas merupakan salah satu aspek dari kualitas manusia yang saat ini sangat berperan penting didalam menunjang pembangunan bangsa dan negara Indonesia yang sedang mengalami permasalahanpermasalahan yang kompleks, sebab dengan kreativitas, manusia akan memiliki kemampuan adaptasi kreatif dan kepiawaian yang imajinatif, sehingga manusia akan mampu mencari penyelesaian masalah dengan cara yang baru didalam mengikuti perubahanperubahan yang terjadi yakni akan terus bergerak kearah kemajuan untuk tidak hanyut dan tenggelam dalam persaingan antar bangsa dan negara, terutama didalam era globalisasi ini.

Kreativitas di dalam pendidikan yaitu bila siswa mengerti suatu cara diluar dari kebiasaannya dan tetap tenang untuk menyelesaikan masalah di dalam kelompoknya. (Sternberg, 1999). Kreativitas adalah proses penyatuan pengetahuan dari berbagai bidang pengalaman yang berlainan untuk menghasilkan ide yang baru dan lebih baik. (West, M, 2000). Ford (dalam West, M., 2000), menyatakan bahwa kreativitas adalah suatu 
pertimbangan subyektif dan berkontek spesifik mengenai kebaruan dan nilai suatu hasil dari perilaku individual dan kolektif.

Menurut Cambell (1986), dan Glover (1990), kreativitas merupakan kegiatan yang mendatangkan hasil yang sifatnya :baru (novelty), yang berarti invasi, belum pernah ada sebelumnya dan aneh ; berguna (useful), yang berarti lebih praktis, mempermudah, mengatasi kesulitan, dan menghasilkan yang lebih baik ; dimengerti (understandable), yang berarti hasil yang sama dapat dimengerti atau dipahami dan dapat dibuat pada waktu yang berbeda.

\section{ADVERSITI}

Manusia dilahirkan dengan satu dorongan inti yang manusiawi untuk terus mendaki, dalam arti untuk terus menggerakkan tujuan hidupnya kedepan. Pendakian ini bisa berkaitan dengan usaha didalam mendapatkan nilai yang bagus, memperbaiki hubungan dengan teman sekolah, menjadi lebih mahir dalam segala hal yang sedang dikerjakan, menyelesaikan satu tahap pendidikan, memberikan kontribusi yang berarti selama masa hidup, mendekatkan diri pada Tuhan, dan lain-lain. Orang-orang yang sukses memiliki dorongan yang mendalam untuk berjuang, untuk maju, untuk meraih cita-cita dan mewujudkan impiannya. Untuk dapat memahami dan memperbaiki komponen dasar pendakian seseorang sehari-hari dan seumur hidup diperlukan gabungan ketiga unsur yang meliputi : kerangka kerja koseptual yang baru, tolok ukur untuk mengetahui respon seseorang terhadap kesulitan yang dihadapi, dan peralatan yang praktis. Gabungan ketiga unsurmerupakan bentuk dari tingkat kemampuan seseorang untuk menggerakkan tujuan hidupnya kedepan yang merupakan tingkat kemampuan untuk bertahan dan mengatasi kesulitan yang dihadapiyang diperkenalkan olehStoltz (2000) sebagai Adversity Quotient. Menurut Stoltz (2000), pertama, AQ merupakan suatu kerangka kerja konseptual yang baru untuk memahami dan meningkatkan semua segi kesuksesan : kedua, AQ merupakan suatu ukuran untuk 
mengetahui respon anak terhadap kesulitan ; ketiga, AQ merupakan serangkaian peralatan yang memiliki dasar ilmiah untuk memperbaiki respons anak terhadap kesulitan. Didalam merespons suatu kesulitan untuk mencapai kesuksesan terdapat tiga kelompok tipe manusia ditinjau dari tingkat kemampuannya. (Stoltz, 1997). :

a. Quitters adalah individu yang memilih keluar, menghindari kewajiban, mundur dan berhenti apabila menghadapi suatu kesulitan. Individu-individu ini menolak kesempatan yang diberikan dan mengabaikan, menutupi, atau meninggalkan dorongan inti yang manusiawi untuk mendaki, sehingga meninggaikan banyak hal yang ditawarkan oleh kehidupan, berarti adversity quotient pada tipe quitters ini rendah.

b. Campers adalah individu yang pernah mencoba menyelesaikan suatu kesulitan dan sekurangkurangnya telah menanggapi tantangan pendakian yang ada, namun individu tersebut akan berhenti ketika pendakian awalnya dirasa sudah sampai tanpa mau berusaha mempertahankan hasil pendakian tersebut selama kehidupannya. Adversity quotient pada tipe campers tergolong sedang.

c. Climbers adalah sebutan untuk individu yang seumur hidup membaktikan dirinya pada pendakian. Individu ini merupakan pemikir yang selalu memikirkan kemungkinan-kemungkinan dan tidak pernah membiarkan umur, jenis kelamin, ras, cacat fisik, atau mental, atau hambatan lainnya yang bisa menghalangi pendakiannya. Tipe climbers termasuk individu yang mempunyai adversity quotient tinggi.

\section{INTELIGENSI}

Binet (dalam Azwar, 1996), menyatakan bahwa inteligensi terdiri dari tiga komponen, yaitu : kemampuan untuk mengarahkan pikiran ataumengarahkan tindakan; kemampuan untuk mengubah arah tindakan bila tindakan tersebut telah dilaksanakan ; dan kemampuan untuk mengkritik diri sendiri. 
Goddard, mengatakan bahwa inteligensi sebagai tingkat kemampuan pengalaman seseorang untuk menyelesaikan masalahmasalah yang langsung dihadapi dan untuk mengantisipasi masalahmasalah yang akan datang, sedangkan V.A.C Henmon, mengatakan bahwa inteligensi terdiri dari dua macam, yaitu : kemampuan untuk memperoleh pengetahuan; dan pengetahuan yang diperoleh. (dalam Azwar,1996).

Lewis Madison Terman, mengatakan bahwa inteligensi merupakan kemampuan seseorang untuk berpikir abstrak, sedangkan Edward Lee Thorndike, mengatakan bahwa inteligensi adalah kemampuan dalam memberikan respon yang baik terhadap pandangan kebenaran atau fakta. (dalam Azwar,1996).

Inteligensi bukan kemampuan tunggal dan seragam, tetapi merupakan komposit dari berbagai fungsi, sehingga mencakup gabungan kemampuan-kemampuan yang diperlukan untuk bertahan dan maju dalam budaya tertentu. (Anastasi, 1997).
David Wechsler (1958), berpendapat bahwa inteligensi adalah kumpulan atau seluruh kapasitas individu untuk bertindak sesuai tujuan, berpikir secara rasional dan bertindak secara efektif dengan lingkungannya. Inteligensi sebagai suatu kumpulan atau keseluruhan karena tersusun dari elemen-elemen atau kemampuan-kemampuan yang tidak seluruhnya bebas. Didalam lingkungan masyarakat umum sering terjadi miskonsepsi populer tentang IQ yang dipandang sebagai singkatan untuk inteligensi. Masyarakat umum banyak yang belum memahami bahwa IQ merupakan hasil skor dari tes kemampuan intelektual. Inteligence Quotient (IQ) adalah ekspresi dari tingkat kemampuan individu pada saat tertentu, dalam hubungan dengan norma usia tertentu yang ada. IQ merupakan cerminan dari prestasi pendidikan sebelumnya dan alat prediksi kinerja pendidikan selanjutnya

Untuk mempertimbangkan nilai numerik sebuah IQ, harus menentukan secara spesifik tes yang menjadi sumber IQ tersebut. Menurut Weiten (1992), tes-tes 
inteligensi umum yang dirancang untuk digunakan bersama anak-anak sekolah sering dilakukan secara kelompok dan biasanya mengukur kemampuan-kemampuan verbal, tetapi juga mencakup kemampuan yang berkaitan dengan simbol numerik dan simbol abstrak yang lain dalam kadar yang lebih rendah. Kemampuan-kemampuan tersebut dominant dalam proses belajar di sekolah, oleh karena itu kemampuankemampuan tersebut dapat dipandang sebagai ukuran kemampuan belajar atau inteligensi akademik. Hal ini didukung oleh pendapat David Wechsler (1958), yang menyatakan bahwa Inteligensi sebagai suatu kumpulan atau keseluruhan karena tersusun dari elemen-elemen atau kemampuankemampuan yang tidak seluruhnya bebas, oleh karena itu kemampuankemampuan yang diukur tersebut dapat digunakan untuk mengevaluasi inteligensi dan inteligensi bukan sekedar jumlah dari kumpulan kemampuan tersebut. Terdapat tiga alasan yang mendasari pendapat Wechsler, yaitu :Hasil akhir tingkah laku inteligensi adalah fungsi dari sejumlah kemampuan dan cara kemampuan tersebut bergabung atau konfigurasi kemampuan-kemampuan yang ada. ; Ada beberapa faktor selain kemampuan intelektual, misal : dorongan, insentif;Urutan tingkah laku inteligen berbeda, sehingga urutan kemampuan yang dibutuhkan juga berbeda. Juga didukung oleh Anastasi (1997), yang menyatakan bahwa inteligensi bukan kemampuan tunggal dan seragam, tetapi merupakan komposit dari berbagai fungsi, sehingga mencakup gabungan komponen-komponen yang diperlukan untuk bertahan dan maju didalam budaya tertentu. Oleh karena itu tes inteligensi untuk siswa SMU yang digunakan dalam penelitian ini adalah Inteligenz Struktur Tes (IST) yang dikembangkan di Frankfurt Jerman oleh Rudolf Amthauer, karena IST mengukur bermacam-macam kemampuan individu dan dapat dilaksanakan secara kelompok dan tes ini direkonstruksi untuk orang usia 14 sampai dengan 60 tahun. Tes IST telah diadaptasi di Indonesia dan dimanfaatkan oleh Psikologi Angkatan darat (Psi-AD) Bandung 
yaitu bapak Bob Dengah dan kawankawan. Selanjutnya dikembangkan oleh Biro Psikologi Persona Bandung dan akhirnya mencapai bentuk yang sekarang banyak dipergunakan. Tes IST yang sudah diadaptasi ini sudah banyak digunakan diberbagai tempat di Indonesia, khususnya di Jawa Timur (Winarti,1998). IST mampu mengukur inteligensi secara menyeluruh dan inteligensi khusus bagi seseorang.

\section{HASIL PENELITIAN}

Berdasarkan hasil analisis regresi diperoleh nilai $\mathrm{F}=6,401$ dengan sig. $=0,042$ yang berarti ada hubungan antara adversiti dan inteligensi dengan kreativitas. Untuk melihat subangan efektif masil-masil variabel diperoleh $19,12 \%$ sumbangan variabel adversiti terhadap kreativitas siswa, dan $30,23 \%$ sumbangan variabel inteligensi terhadap kreativitas siswa.

\section{PEMBAHASAN}

Semakin seorang siswa mempunyai respon yang baik atau mempunyai kemampuan untuk bertahan dan kemampuan mengatasi kesulitan yang dihadapi serta didukung oleh kecerdasan yang cukup tinggi, maka semakin tinggi pula kreativitas atau semangat berkreasinya. Hal ini sesuai dengan pendapat Sternberg dan Lubart (1995), yang cenderung memandang bahwa proses-proses kreatif dapat berlangsung karena keterlibatan fungsi-fungsi intelektual dan sekaligus juga fungsi-fungsi karakteristik kepribadian seseorang yang relevan dengan proses-proses kreatif tersebut, yang didasari oleh penelitian Sternberg (1985), dengan ditunjukkannya bahwa orang kreatif memiliki kemampuan dan kemauan untuk berpikir dan bertindak di atas batas-batas realitas diri dan lingkungannya, yang mengindikasikan bahwa untuk menghasilkan karya-karyakreatif dalam bidang penelitian ilmiah atau seni, selain membutuhkan peran intelektual juga karakteristik kepribadian tertentu dari seseorang. Konsekuensinya, didalam mengungkap potensi kreatif yang hanya menekankan pada kemampuan intelektual seperti berpikir divergen 
adalah tidak cukup, tetapi juga harus mencakup karakteristik kepribadian yang dianggap relevan yang keduanya dibutuhkan di dalam proses-proses kreatif yang produktif dan bermutu. Kemudian (Sternberg, 1988), menuangkan di dalam teorinya tentang kreativitas, yang menyatakan bahwa kreativitas merupakan titik pertemuan yang khas antara tiga atribut psikologis : inteligensi, gaya kognitif, dan kepribadian atau motivasi, yang secara bersamaan membantu memahami apa yang melatar belakangi individu yang kreatif. Sternberg (1995), juga menyatakan bahwa penting untuk menyumbang sumber daya dalam kasus kreatif adalah latar belakang pengetahuan dan pengalaman (kecerdasan), ketekunan (kepribadian), dan dukungan dari lingkungan.

Total sumbangan efektif adversiti dan inteligensi tergolong kecil, tetapi tetap mempunyai peran didalam meningkatkan kreativitas; sehingga untuk meningkatkan kategori kreativitas siswa Indonesia agar siap menjadi daya dukung yang berkualitas didalam memulihkan bangsa dan negara Indonesia dari situasi krisis, siswa Indonesia perlu memiliki kecerdasan yang cukup tinggi dan memiliki kemampuan bertahan ataupun kemampuan mengatasi kesulitan dalam permasalahan yang dihadapi. Oleh karena itu kondisi siswa yang ratarata mampu memunculkan kreativitasnya perlu dipertahankan bahkan ditingkatkan, yang dapat dilakukan melalui peningkatan potensi dasar siswa dengan cara sering memberikan latihan atau tugas-tugas yang membutuhkan kemampuan intelektualnya baik didalam melibatkan kegiatan berpikir konvergen maupun kegiatan berpikir divergen, dan juga melalui perbaikan adversiti siswa seperti yang dikemukakan oleh Stolz (2000), yaitu siswa sering mendapatkan latihan-latihan melalui metode LEAD seperti yang sudah dijelaskan di depan.

Hasil tambahan dari analisis data, menyatakan ada hubungan positif yang signifikan antara adversiti dengan kreativitas. Artinya semakin baik adversiti siswa, maka semakin tinggi kreativitasnya atau 
semakin siswa mampu memberikan respon yang baik atau mampu bertahan dan mampu mengatasi kesulitan yang dihadapi, semakin tinggi semangat berkreasinya. Hal ini sesuai dengan pernyataan Stolz (2000), bahwa salah satu manfaat dari adversiti adalah kreativitas artinya ketidak berdayaan yang dipelajari yang akan membentuk orang-orang yang tidak mampu menghadapi kesulitan, bisa menghancurkan kreativitas orang yang cemerlang. Oleh karena itu orang yang tidak mampu bertahan didalam menghadapi kesulitan atau responnya terhadap kesulitan buruk, akan tumbuh menjadi orang yang tidak mampu bertindak kreatif. Meskipun sumbangan adversiti terhadap kreativitas kecil, bahkan lebih kecil bila dibandingkan dengan sumbangan inteligensi terhadap kreativitas, tetapi untuk meningkatkan semangat kreatif yang tinggi tetap memerlukan kemampuan bertahan dan mengatasi kesulitan terhadap permasalahan yang dihadapi sebab untuk dapat berpikir kreatif harus melalui beberapa tahap, terutama tahap inkubasi yaitu situasi setelah berhenti menyelesaikan masalah yang belum selesai dan kemudian mendapatkan cara penyelesaian tepat yang membutuhkan waktu lama.Yang memungkinkan sumbangan adversiti lebih kecil dari pada sumbangan inteligensi terhadap pengembangan kreativitas, karena adversiti hanya diperlukan pada saat mendukung munculnya situasi yang sulit dalam menyelesaikan permasalahan, sementara itu inteligensi selalu dibutuhkan dukungannya sebagai kemampuan-kemampuan yang mendasari munculnya ide-ide yang baru dan bermanfaat.

$$
\text { Inteligensi mempunyai }
$$
hubungan positif yang sangat signifikan dengan kreativitas, artinya semakin tinggi tingkat inteligensi seseorang,semakin tinggi pula kreativitasnya atau semakin mempunyai semangat berkreasi yang tinggi. Hal ini sesuai dengan teori ambang inteligensi untuk kreativitas dari Anderson (dalam Munandar, 1999), bahwa sampai tingkat inteligensi tertentu, yang diperkirakan IQ 120, ada hubungan yang erat antara inteligensi dengan 
kreativitas yaitu kreativitas yang tinggi memerlukan tingkat inteligensi yang cukup tinggi pula, tetapi diatas ambang inteligensi tersebut tidak ada korelasi yang tinggi lagi antara inteligensi dengan kreativitas. Sementara itu data yang diambil sebagai sampel penelitian menunjukkan tingkat inteligensi siswa berada pada kategori rata-rata atau diatas rata-rata, tidak ditemui siswa dengan tingkat inteligensi yang sangat tinggi, sehingga hasilnya menyatakan bahwa inteligensi mempunyai hubungan positif yang sangat signifikan dengan kreativitas. Hasil tersebut juga didukung oleh penelitian-penelitian sebelumnya, antara lain penelitian yang dilakukan oleh Utami Munandar (1977), menunjukkan bahwa berpikir divergen (kreativitas) mempunyai hubungan yang bermakna dengan berpikir konvergen (inteligensi) ; dan dari penelitian yang dilakukan oleh Getzels dan Jackson (1970), dapat disimpulkan bahwa ada hubungan antara kreativitas dengan inteligensi walaupun hubungan itu tidak begitu kuat. Hal tersebut sesuai dengan hasil penelitian Munandar (1982) dan Sinambela (1993), yang menemukan ada hubungan antara inteligensi dengan kreativitas, walaupun hubungannya rendah. Sumbangan efektif inteligensi terhadap kreativitas tergolong kecil, tetapi masih lebih besar dibandingkan sumbangan efektif adversiti terhadap kreativitas. Artinya kecerdasan yang dimiliki siswa hanya menyumbang sebagian kecil untuk dapat mengembangkan kreativitas tetapi tetap mempunyai peran yang lebih besar sebagai landasan pengetahuan dan pengalaman dalam mengembangkan kreativitas, sehingga kecerdasan yang cukup tinggi perlu dimiliki untuk mendukung terciptanya daya kreasi seorang siswa. Sumbangan yang lebih besar mungkin diberikan oleh sumber-sumber pengaruh yang lain untuk pengembangan kreativitas, seperti gaya berpikir, motivasi, lingkungan yang perlu diteliti sebagai penelitian lanjutan.

\section{KESIMPULAN}

Didalam menghadapi situasi krisis yang sedang melanda bangsa dan negara Indonesia, dibutuhkan 
tunas muda bangsa yang berkualitas. Salah satu aspek dari kualitas manusia adalah kreativitas, yang berperan penting sebagai daya dukung untuk dapat bangkit dari permasalahan yang kompleks dengan kemampuan adaptasi kreatif yang merupakan kemampuan mencipta untuk dapat mengikuti perubahanperubahan yang terjadi, yang akan bergerak kearah kemajuan dan memungkinkan untuk dapat melihat berbagai macam solusi permasalahannya sehingga mampu bangkit dari situasi krisis. Sedangkan kreativitas tunas muda atau siswa Indonesia dalam kategori rendah, maka perlu adanya pengembangan. Sumber-sumber yang mempengaruhi pengembangan kreativitas antara lain kepribadian dan kecerdasan, maka penelitianbertujuan untuk mengetahui adanya hubungan positif antara adversiti (konsep baru tentang kepribadian berdasarkan pendapat Stoltz) dan inteligensi (kecerdasan) dengan kreativitas.

Kreativitas merupakan suatu proses penyatuan pengetahuan dari berbagai bidang pengalaman yang berlainan untuk menghasilkan ide- ide yang bermanfaat dengan cara baru dan lebih baik serta mampu merealisasikannya; dan kreativitas merupakan titik pertemuan yang khas antara tiga atribut psikologis yaitu inteligensi, gaya kognitif, dan kepribadian, yang secara bersamaaan membantu memahami apa yang melatar belakangi individu yang kreatif. Inteligensi adalah ekspresi tingkat kemampuan tertentu siswa berdasarkan pengetahuanpengetahuan dan pengalaman yang diperoleh, dan adversiti merupakan kemampuan siswa didalam melakukan respon yang baik terhadap kesulitan yang dihadapi atau kemampuan siswa untuk bertahan dan mengatasi kesulitan yang dihadapi di dalam mendaki tujuan yang akan dicapai. Ketidakberdayaan yang dipelajari yang akan membentuk orang-orang yang tidak mampu bertahan menghadapi kesulitan, akan tumbuh menjadi orang yang tidak mampu bertindak kreatif dan kreativitas yang tinggi memerlukan tingkat inteligensi yang cukup tinggi pula. Oleh karena itu hipotesis yang diajukan menyatakan bahwa untuk dapat 
meningkatkan didalam menghasilkan ide-ide yang bermanfaat dengan cara yang baru dan lebih baik, diperlukan tingkat inteligensi yang cukup tinggi dan didukung dengan kemampuan melakukan respon yang baik terhadap kesulitan yang dihadapi didalam mendaki memunculkan ide kreatif tersebut; dengan kata lain ada hubungan positif antara adversiti dan inteligensi dengan kreativitas siswa..

\section{DAFTARPUSTAKA}

Anastasi, A., dan Urbina, S. 1998. Psychological Testing. Terjemahan Prenhallindo, Jakarta.

Azwar, S. 1996. Pengantar Psikologi Inteligensi. Pustaka Pelajar, Yogyakarta.

Azwar, S. 1992. Reliabilitasdan Validitas. Pustaka Pelajar, Yogyakarta.

Azwar, S. 1999. Penyusunan Skala Psikologi. Pustaka Pelajar, Yogyakarta.

Campbell, D. 1986. Mengembangkan Kreativitas. Kanisius, Jakarta.

Csikszentmihalyi, M. 1996. Creativity : Flow and The Psychology of Discovery and Invention. Harper Collins Publishers, New York.
Diana, R.1999. Hubungan antara Religius dan Kreativitas Siswa Sekolah Menengah Umum, Jurnal Psikologika UII. Nomor 7 Tahun III,5-25.

Depdikbud. 1995. Kamus Besar Bahasa Indonesia, edisi kedua. Balai Pustaka, Jakarta.

Freeman, S.F. 1965. Psychological Testing, Oxford and Ibit Publishing Co, New Delhi.

Glover, J. dan Burning, R.H. 1990. Educational Psychology : Principles and application $3^{\text {rd }}$ edition. Harper Collins Publishers, New York.

Hadi, S. 1991. Metodologi Research, jilid 3. Andi Offset, Yogyakarta.

Hadi, S. 2000. Seri Program Statistik. Universitas Gajah Mada, Yogyakarta.

Hari, K.L. 2001. Tinjauan Singkat Adversity Quotient. Indonesian Psychological Journal, Anima, No. 1, Vol. 17, 63 - 68.

Hurlock, E. 1997. Perkembangan Anak, jilid II,Erlangga, Jakarta.

Monks, F.J., dkk. 1989. Psikologi Perkembangan : Pengantar dalam berbagai bagiannya, Gajah Mada Unversity Press, Yogyakarta.

Munandar, S.C.U. 1999. Kreativitas dan Keberbakatan : StrategiMewujudkan Potensi Kreatif dan Bakat, Gramedia Pustaka Utama, Jakarta. 
Munandar,S.C.U.

1999.

Pengembangan

Kreativitas

Anak-anak Berbakat, Rineka Cipta, Jakarta.

Soeparman. 2000. Hubungan Kemandirian dan Kreativitas Siswa Sekolah Menengah Umum. Jurnal Filsafat, Teori dan Praktek Kependidikan. FIP Universitas Negeri Malang, No. 1, Th.27, 92- 97.

Stoltz, P.D. 2000. Adversity Quotient: Turning obstacles into Oppotunities.

Terjemahan ,Grasindo., Jakarta.

Suharnan, 2002. Skala C.O.R.E. sebagai Alternatif Mengukur Kreativitas: Suatu Pendekatan Kepribadian. Indonesian Psychological Journal, Anima, No. 1, Vol. 18, 36 - 56.

Suryabrata, S. 2000. Pengembangan Alat Ukur Psikologis, Andi, Yogyakarta.

Tjundjing, S. 1999 Hubungan Antara IQ, EQ, dan AQ dengan Prestasi Studi Pada Siswa SMU. Indonesian Psychological Journal, Anima, No.1, Vol.17, $69-92$.

Weiten, W. 1992. Psychology : Themes and Variations, Second Edition, Brooks/Cole Publishing Company, New York.

West, M. 2000. Mengembangkan Kreativitas dalam Organisasi. Kanisius, Jakarta.
Yoenanto, N.H. 2002. Hubungan

Kemampuan Memecahkan Soal

Cerita

MatematikaDenganTingkat

Kreativitas Siswa Sekolah

Menengah Umum. Jurnal

Psikologi Unair Insan, No.2, Vol.4, 63-72. 
